\title{
"In Dublin's fair city" Walter Somerville: the early years
}

\author{
EOIN O'BRIEN \\ From The Charitable Infirmary, fervis Street, Dublin
}

Walter Somerville was born on 2 October 1913 in Clontarf, then a small seaside suburb of Dublin. His father Patrick was a Dubliner and his mother Catherine came from Roscommon. Walter joined his 2-year-old sister Eileen to complete a close and happy family. In the early years of the century few places could have vied with Clontarf for scenic beauty, and the variety of pleasure available to young children was incomparable. The sea of Dublin Bay virtually lapped the roadside; the Bull Wall led to exciting waters and dunes; for an outing there was Howth with its picturesque fishing harbour, or the seaside resort of Portmarnock; there was the thrill of a boat trip to Lambay Island with its birds and breathtaking scenery, and the Dublin and Wicklow mountains overlooking the city and its bay were within easy reach for a family picnic. On dull winter afternoons Dublin children flocked to the pictures in frenzied excitement. There was such a selection of marvellous cinemas in those days-"The Lux" (De-Luxe), "The Tivo" (Tivoli), The Pillar, The Grand Central, The New Electric, The Grafton, and The Cameo. These cinemas were more like community centres than mere picture houses. The discerning and very talkative young audience had their own simple way of categorising the characters of the screen be they of the western (by far the most popular), romantic, or classical genre. The hero was known as "The Fella" and his girlfriend was "The Mot"; "The Fella" invariably had a "Pal", an accomplished horse or dog which could with consummate skill extricate him and his "Mot" from the machinations of the "Head Crook" and his unsavoury "Mot".

At the age of 11 Walter was sent to the Jesuit School, Belvedere College. Situated a stone's throw from O'Connell Street, Belevedere was and still is one of Ireland's leading Catholic schools. From an imposing Georgian five-bay mansion generations of schoolboys have gazed over the rooftops of the city towards the Liffey to where the Custom House dome rises. Belvedere House was built for the second Earl of Belvedere in 1786 by Michael Stapleton whose reputation as "the Dublin master of the silver age" is truly exemplified in the extravagant plaster and stucco work of the generously proportioned halls and rooms. The Diana Room or Library complete with the original mahogany organ and book cases, and the Apollo Room with its ornate ceiling survive unchanged, but in the Venus Room the centre piece of an undraped maiden reclining upon clouds was removed when the Jesuits took over the building in 1841, presumably lest the eyes of their schoolboy charges be directed heavenwards a little too constantly. Bronze medallions with an Apollo motif decorate the staricase handrails, and the Bossi fireplace in the chapel calls to mind an age that devoted more time and money (Belvedere practically beggared himself in building the house) to aesthetic rather than functional considerations. The chapel of Belvedere was, as in the other major Catholic schools, the nidus of spiritual instruction and development, as one named James Joyce who had sat there 25 years before Walter has recorded in pungent tones-"The chapel was flooded by the dull scarlet light that filtered through the lowered blinds; and through the fissure between the last blind and the sash a shaft of wan light entered like a spear and touched the embossed brasses of the candlesticks upon the alter that gleamed like the battle-worn mail armour of angles". Joyce found even less favour with his Jesuitical mentors than with Ireland's censors, and his early writings would not, we can take it, have been a topic for discussion in Belvedere during Walter's schooldays. It would not have been long, however, before Walter's literary curiosity drew him to compare notes with his (now) distinguished literary predecessor. What, we can only ask ourselves, would he have thought of Joyce's vivid description of the sermon on hell which was to send Stephen Daedalus reeling from the college chapel-"Every sense of the flesh is tortured and every faculty of the soul therewith; the eyes with impenetrable 
utter darkness, the nose with noisome odours, the ears with yells and howls and execrations, the taste with foul matter, leprous corruption, nameless suffocating filth, the touch with redhot goads and spikes, with cruel tongues of flame ..."

Walter's time at Belvedere was by all accounts happy. He did what was asked of him academically, but he was not, it would seem, motivated to excel. We find special mention of him in The Belvederian of 1930 when he was a member of a debating group. Was it here that he began to develop those skills that were later to so impress medical audiences? He indulged in sport as required, and though not an overenthusiastic participant, he developed a keen interest in rugby and cricket.

At Belvedere some of the characteristics that formed the man to whom this volume is dedicated were moulded and developed, but there were other influences. Even at this distance in time we can detect the warmth of the Clontarf home where at an early age Walter was directed towards music which was to be his abiding interest until medicine later took precedence. A talented musician Professor Jarlett Smith was engaged by Walter's parents to teach the children to play the piano, and he was a regular caller to Clontarf over many years. Under his tuition Walter became quite an accomplished pianist, but perhaps more important Professor Smith, a man of broad cultural interest, developed his pupil's aesthetic sensibilities.

From Belvedere Walter went to University College, Dublin, where he began the study of medicine in 1931. He attended lectures at the University's main building in Earlsfort Terrace, and for clinical instruction he went to the Mater Misericordiae Hospital in Eccles Street. Though the medical student of the thirties attended mainly his own hospital, he was free to go to clinics at any of Dublin's many teaching hospitals, and Walter would surely have dropped in on "The Abe" (Leonard Abrahamson) at the Richmond Hospital, and Alfie Parsons at Baggot Street, and there would have been the attraction of "Pops" Morrin, James Meenan, and Bill Doolin in St. Vincent's. At the Mater it is likely that Henry F. Moore, consulting physician and professor of medicine at University College, Dublin, would have been a potent influence on the young Somerville. Moore, a brusque man with a difficult personality, had an unusual medical pedigree for those times. Having graduated with first-class honours he went to the Rockefeller Institute in New York where he spent three years engaged in research in the treatment of pneumonia. At the Mater he established one of the first diagnostic laboratories in Ireland, and he was one of the pioneers of electrocardiography. He failed in his ambition to establish a first class department of medicine, and indeed were he to return today his words of 1930 would be no less prescient- "No money seems to be available for clinical research in this country today, and indeed, little interest, alas, is displayed in it by public bodies or private philanthropists". Unpopular with many of his colleagues he did achieve a probably unique distinction when resigning from St. Michael's Hospital in a fit of pique; the honorary secretary of the medical board was requested to recommend the acceptance of his resignation and to express to Dr Moore the board's pleasure in so doing.

Walter's class included many talented students, one of the brightest being Gerald Fitzgerald with whom Walter was very close. In 1935 Gerald Fitzgerald was awarded the Gold Medal of the Medical Society and in the following year the award was made to Walter Somerville for his paper on "Histidine and gastric disorders". Both students graduated $\mathrm{MB}$ BCh BAO NUI, on 6 July 1937. The friendship was brought to a sad close with the death of Gerald Fitzgerald a few years later.

Walter was appointed house physician to the Mater Hospital then the largest hospital in Ireland with 412 beds. The resident doctor of the thirties in Dublin worked hard in the mornings and when on duty, but the afternoons were often free, and outside there was much excitement within easy reach of a bicycling doctor with a few pennies to jingle. The bicycle was then and for many years to come the chief mode of transport for the Plain People of Ireland who were as Flann O'Brien was to put it themselves half bicycle by virtue of the passage of "mollycules" from backside to saddle "pari passu and vice versa". The newly fledged doctor could, of course, have discarded the faithful velocipede for the motor car. The new Vauxhall 10 which did over $60 \mathrm{mph}$ and $40 \mathrm{mpg}$ complete with hydraulic brakes, ventilation, and a silent synchromesh gearbox was advertised in 1937 for a mere $£ 245$. Cheap though it sounds it was well beyond the reach of Walter whose salary in the Mater was 35 shillings a week, with 25 shillings deducted for accommodation.

But what of outside of the hospital and university? Dublin of the thirties was small, vibrant, and full of fun-"the largest village in Europe" as it was known. There were the sounds now gone forever-horses' hooves and steel wheels on cobbles; the electric tram; newspaper vendors shouting - "Herryamail, Herryamail - Mandrake does it again, read all about it"; the phut phut of a Guinness barge going up the Liffey; children 
shrieking at play. There were the smells, some happily gone like those of the river "Sniffy", and the odours from O'Keefe's knackers yard, but the rich smell of hops and porter from James's Gate is no longer as pungent, though happily the aroma of coffee from Bewleys is still with us. Gone too are Nelson's Pillar, the great Bovril sign dancing "through its seven phases" as Beckett was to put it, and the OXO sign from which engineer Joe is said to have fallen to his untimely death

"Here is my ode to engineer Joe,

Whe fell to his death through the $\mathrm{O}$ in OXO,

He has gone to a land which is far far better,

He went as he came through a hole in a letter" was how the irreverent wit of Oliver St. John Gogarty commemorated the event.

Then there were the street characters. "Bang Bang" leaning precariously from the No. 10 bus pointing his key at passers by and shouting "bang bang, you're dead", and "Endymion" complete in deer stalker hat, knee breeches, tunic shirt, buckled shoes, a few spare swords, a fishing rod, and an umbrella raised on fine days, and folded in wet weather was to be seen fishing through the railings of Trinity College, or consulting his compass to plot his course homewards.

What restaurants and cafes they had in those days. For morning coffee on Grafton Street there was Mitchell's, Bewley's, Roberts, Fullers, and Switzers. In the newly-built Clarence, $\mathbf{M r}$ Hitchcock, late of the famous old Moira ensured that the cooking butter was fresh and pure, that each sauce of sole and pate had what it demanded of time and ingredients, and that loving care was given to the "Clarence Special" (a filleted steak-en tournedos). Close by was the historic Dolphin where Monsieur Leon David would see that the traditional Henry IV steak with its true bearnaise sauce, the "monkeygland steak", and the sole bonne femme were cooked to perfection for very modest prices. What Edwardian splendour there was in this excellent establishment. In Trinity Street there was the old Moira with fine good waiters and true where one could find civilised men, with Trinity undergraduates learning to be men. In Dame Street there was the popular Cafe Belge, and the subterranean chophouse, the Bodega where Gogarty and Seamus O'Sullivan held court. On Stephen's Green the Country Shop (alas recently closed) provided a cheap set lunch, and at the upstairs counter all sorts of spicy patties drew contented crowds to food that was always fresh, hot, and clean. In Duke Street there was FMs where food was fresh and tasty, and the clientele was very genteel. Across the road there was the famous Bailey renowned for its charcoal grill, and-in season-Galway Bay oysters. Its literary tradition of the thirties was to be carried through to the fifties and the sixties. There were the hotels, most of which are still with us, but somehow they now seem to lack the comfort and warmth of those halcyon days-the Hibernian, the Wicklow, the Gresham, and the Shelbourne. And the Stephen's Green clubs have surprisingly survived the ravages of an inflationary age.

But gone for all time alas is that most famous of Dublin epicurean institutes-Jammet's, where the literati, actors, painters, doctors, lawyers, politicians, and an occasional medical student whose fortunes had been graced by a win at the horses rubbed shoulders. Yes, one feels Walter would have found his way there more than once. He might have started with an hors d'oeuvres at $1 \mathrm{~s} 6 \mathrm{~d}$, or a lobster cocktail at $12 \mathrm{~s} 6 \mathrm{~d}$, to be followed by creme printanière at $1 \mathrm{~s}$, or oeufs cocotte portugaise at $2 \mathrm{~s} 6 \mathrm{~d}$, and then the choice was truly dazzling from Irish stew at $2 \mathrm{~s} 6 \mathrm{~d}$. to homard à l'Americaine at $4 \mathrm{~s}$ to tournedos chasseur at $3 \mathrm{~s} 6 \mathrm{~d}$, or wild duck at $6 \mathrm{~s}$ and grouse at $7 \mathrm{~s}$. What a menu, what company; would that we could switch the clock back just for one evening.

And what would our young doctor have been reading? The giants of the literary renaissanceYeats, Gregory, Moore, and Synge were being followed by the likes of O'Casey, O'Flaherty, Kate $O^{\prime} B r i e n$, and James Joyce, and one had yet to hear of Samuel Beckett and Brian O'Nolan. Mind you the censor was doing his best to render the works of most Irish writers unobtainable at home. Some interesting painters were beginning to make their mark on this long neglected aspect of Irish artSean O'Sullivan, Estella Solomons, Leo Whelan, Jack B Yeats, and the not yet appreciated Cecil Salkeld. Then there was the theatre-the old Abbey, and the Gate where a "bob" brought a reasonable seat, and for much less one could enjoy the comedy and wit of "the Gods" at the Gaiety. Walter might have been fortunate enough to be at Denis Johnston's "The Moon in the Yellow River" when it was first produced at the Abbey Theatre on Monday, 27 April, 1931, with such incomparables in the cast as Maureen Delaney, Eileen Crowe, Arthur Shiels, Michael J Dolan, and F J McCormack. In the Gaiety yet another Belvederian Jimmy O'Dea was bringing a new image to pantomime and light comedy with the creation of characters such as "Biddy Mulligan the Pride of the Coombe". The gramophone was giving the songs of Percy French a new popularity and one did not have to go far to hear the strains of

"Come back Paddy Reilly, to Ballyjamesduff, Come home Paddy Reilly to me".

But it was to the old Theatre Royal that Walter 
would have been most attracted. Here he heard Paderewski, the young Yehudi Menuhin, and his very favourite Joseph Hislop. Street musicians made queuing for a cheap seat a pleasurable enough experience, and outside the Royal the sweet voice of Lilian McEvoy often surpassed the entertainment within; her great moment came in 1932 when Fritz Kreisler on his way in to perform in the Royal heard her singing and arranged a week's engagement for her and, the story goes, the street's loss was theatre's gain.

Through Walter's association with the Fitzgerald family there was to come another friendship with an interesting medical figure of the period-John Charles ("JC") Flood. Flood had graduated in 1924, specialised in surgery, and in addition to picking up an $M D$ and $M C h$, he had also acquired a BA, and B Comm and became a barrister-at-law. $\mathrm{He}$ was surgeon to the Charitable Infirmary, and gynaecologist to St Michael's Hospital. An acerbic and at times cruel wit he gave rein to his oratorical powers at the Literary and Historical Society of University College and at the Academy of Medicine: one evening Professor Leonard Abrahamson - (the Abe) presented a complicated case of rheumatoid arthritis that he had treated over many years with gold. At the end of an erudite presentation which attracted sincere prolonged applause Flood stood up and asked-"Can the learned Professor tell us if, after the good lady's demise, he managed to recover the gold?" The Abe was not amused and later remarked-"Flood has more degrees than a thermometer without the same capacity for registering warmth", and on yet another occasion he said "Your gentile God promised that there would only be one catastrophic flood, and look what he has done."

But let us move a little out of Dublin to the Forty Foot, a male bathing preserve where many years earlier the blasphemous "stately plump Buck Mulligan" alias Oliver Gogarty had blessed the surrounding countryside with his shaving lather, but where now sit J C Flood and Walter Somerville in the early morning sunshine, and the older man is advising the younger on the folly of believing in God. How the Irish love to converse about the abstract and God is the greatest abstraction of all, but what is so delightful about this conversation and not so surprising (if one thinks about it) is the ultimate destiny of the older man. He departed medicine to enter the Novitiate at Ealing Abbey, and was ordained at Saint Anselmo in Rome in 1951. Shortly before his death at Ealing Abbey in 1978 Flood expressed his views on cardiology"Actually, I have very little time for cardiologists, although I do attend one regularly; an extremely nice chap, Dublin of course ... got quite a bright wife too, I believe. Yes, he gives me tablets, a new thing called a something-blocker. He took me off Aldomet, which had suited me quite well for many years without, I might add, lowering my blood pressure one whit, but of course, the Inderal has no effect either. I told Walter, I said to him, there is no point in giving me anything, all will be useless, but he insisted on my taking these, telling me that they were tiny and that I would hardly notice them. I reminded him that I could give him cyanide which he would hardly notice either, apart from the result, at which stage, of course, his observations would be of little avail. Anyway, I take them for Walter, at least, occasionally, when I remember them. Yes, I really have very little time for cardiologists." He saw little future in the auscultation of hearts "Tut, tut! I suppose it could be worse. You hear nothing really, nobody at the bedside believes you have heard anything regardless of what you say. They just keep talking while you listen. It is very difficult to be flamboyant with a stethoscope, very difficult to have style, but I suppose you will get new machinery, something bigger and better than the ECG, play around with it for a while, and then discard it. Mind you, it is very difficult to be an eccentric character in medicine nowadays-you are all paid too well, and when you are well paid there is no need to have flair. Of course, the surgeon has a much better chance, a knife is much more theatrical than a stethoscope, and then there is all the dressing up to go with it. I suppose they even wear makeup nowadays."

This remarkable eccentric in a moment of uncharacteristic endearment once told Walter that he respected him and then hastily advised him never to trust compliments. Accepting the cynical wisdom of Flood's adage, we can on this occasion assure Walter of the warmth and sincerity of this salute from his heritage.

Requests for reprints to Dr Eoin O'Brien, The Charitable Infirmary, Jervis Street, Dublin, Eire. 